\title{
A NOTE ON THE SURFAGE PROFILE OF THE GREENLAND ICE SHEET
}

\author{
By K. Philberth* and B. Federer \\ (Eidg. Institut für Schnee- und Lawinenforschung, Davos, Switzerland)
}

\begin{abstract}
This paper deals with the influence on the surface profile of the Greenland ice sheet, of an accumulation which increases between the ice divide and the coast, and of the thermal softening of the lowermost layers. It is concluded that the form of the surface of the profile measured by E.G.I.G. can be described by Glen's law with the exponent $n=3 \cdot 5$. The assumption is made that the bottom temperature differs everywhere from the pressure melting point by a constant amount. This assumption is dropped in the second part of the paper. On the basis of the measured surface profile it is shown that the maximum increase of the bottom temperature is a few degrees within a range of $300 \mathrm{~km}$. In view of the increasing surface temperature and heat of friction towards the outer edge it is concluded that, relatively close to the ice divide, the ice at the bottom must be temperate. Therefore we conclude that friction forces are preventing the ice
from slipping on the bedrock.
\end{abstract}

Résumé. Sur le profil de la calotte glaciaire du Groenland. On examine l'influence d'une accumulation qui croît entre la ligne de partage et la côte, et d'un ramolissement thermique des couches inférieures, sur le profil de surface de la calotte glaciaire du Groenland. On conclut que la forme de la surface sur le profil mesuré par l'E.G.I.G. est donnée par la loi de Glen avec l'exposant $n=3.5$. Cette conclusion est faite d'après l'hypothèse que la température du socle rocheux diffère d'un montant constant de la température de fusion. Cette hypothèse est abandonnée dans la seconde partie. D'après le profil de la surface mesuré par nivellement, on démontre que la température de la glace au sol n'augmente au maximum que de quelques degrés sur une distance de $300 \mathrm{~km}$. Considérant la température de surface et la chaleur de frottement qui augmentent vers la côte, on conclut que la glace au sol est tempérée à une distance relativement petite de la ligne de partage. Ce sont des forces de frottement qui empêchent le glissement de la calotte sur le lit rocheux.

Zusammenfassung. Über das Oberflächenprofil des grönländischen Inlandeises. Es wird untersucht, welchen Einfluss eine zwischen dem Kulminationspunkt und der Küste ansteigende Akkumulation und eine thermisch bedingte höhere Fluidität der untersten Schichten auf das Oberflächenprofil der grönländischen Eiskalotte hat. Es ergibt sich, dass die Oberfläche auf dem von der E.G.I.G. gemessenen Profil eine Form hat, die durch das Glen'sche Gesetz mit dem Exponenten $n=3.5$ beschreiben werden kann. Dabei ist zunächst angenommen, dass die Bodentemperatur um einen konstanten Betrag vom Druckschmelzpunkt entfernt ist. Diese Annahme wird im zweiten Teil fallen gelassen. Es wird aufgrund des gemessenen Oberflächenprofils gezeigt, dass die Bodentemperatur innerhalb $300 \mathrm{~km}$ höchstens einige Grad zunimmt. Angesichts der nach aussen zunehmenden Oberflächentemperatur und Reibungswärme führt das zum Schluss, dass schon relativ nahe an der Eisscheide das Eis am Felsboden temperiert ist, dass also Reibungskräfte das Eis am Boden festhalten.

Haffeli (I96r); Haefeli and Brandenberger (1968, p. 278) and Weertman (196r) have compared the theoretical and the measured surface profiles of the Greenland ice sheet. Weertman obtained good agreement with a profile measured at lat. $79^{\circ} \mathrm{N}$. In this paper the profile at lat. $71^{\circ} \mathrm{N}$. is considered. For this profile, Haefeli's theory, using in Glen's law $\dot{\epsilon}=K_{\tau}{ }^{n}$ the exponent $n=3 \cdot 5$, is in excellent agreement with the E.G.I.G. measurements. The comparison is made on the assumptions that the accumulation $A$ and the temperature distribution are constant in space and time. In this paper we shall investigate the case where these two assumptions do not hold. However we shall keep Haefeli's other assumptions, which are: the general validity of Glen's law, zero ice velocity at the ice-bedrock interface, equilibrium flow conditions and a horizontal bed.

Many authors have concluded (see Robin, 1955; Lliboutry, 1968; Philberth and Federer, to be published), that the ice is much warmer and more fluid in the vicinity of the bedrock than in the overlying layers. If one takes, for example, a thermal gradient of $\mathrm{I} / 30 \mathrm{deg} / \mathrm{m}$ near the bedrock (caused by the geothermal heat and the heat of friction) and in the thermal factor of Glen's generalized formula as modified by Lliboutry (1968), $\dot{\epsilon}=K_{0} \tau^{n} \exp (k \theta)$, a temperature coefficient $k=0.15 \mathrm{deg}^{-1}$, the result is that at a height $h=300 \mathrm{~m}$ above the bedrock the temperature is decreased by ro deg, which increases the viscosity by a factor $\exp [0.15 \times 10]=4.5$. This means that the ice sheet slips on its lowermost layers as discussed by Nye (1959). Therefore we can make a simplifying assumption

(I) The mean horizontal velocity $v_{x \mathrm{~m}}$ depends only on temperature and shear stress at the bottom of the ice sheet.

* Permanent address: Peter-Roseggerstr. 6, D-8031 Puchheim, Germany. 
Furthermore we assume that

(2) the temperature regime in the ice sheet is stationary,

(3) the difference of the bottom temperature from the pressure melting point is constant, and

(4) the accumulation $A$ is constant in time but increases linearly towards the edge of the ice sheet

$$
A=a_{0}+z x
$$

where $x$ is the distance from the ice divide and $a_{0}$ and $Z$ are constants; $A, a_{0}$ and $Z$ are "ice values". According to our own measurements during the International Glaciological Expedition to Greenland, E.G.I.G. (Federer, 1969), this linear increase is real between Crête and Carrefour with $a_{0}=0.27 \mathrm{~m} /$ year and $z=8 \times 10^{-4} \mathrm{~m} / \mathrm{km}$ year. This is also in agreement with the results of Benson (1962), Mock (1967) and de Quervain (1968, p. 142). In the second part of this paper, assumption (3) will be dropped.

The shear stress $\tau_{B}$ at the bottom of the ice sheet is approximately (if $\alpha$ is small):

$$
\tau_{B}=\rho g y \tan \alpha
$$

where $\rho$ is the density, $g$ the acceleration due to gravity, $y$ the total height above ground and $\alpha$ the slope of the ice surface.

Let $C_{2}, C_{3}, \ldots, C_{\mathrm{ro}}$ be constants, the values of which do not concern us here; they depend on $n$ and $m$ respectively.

The horizontal mean flow velocity $v_{x \mathrm{~m}}$ is given by:

$$
v_{x \mathrm{~m}}=\mathrm{I} / y \int_{0}^{x} A \mathrm{~d} x .
$$

Case (a) (Haefeli, I96r):

$$
\begin{aligned}
C_{2}(y \tan \alpha)^{n} y & =v_{x \mathrm{~m}} \\
(y \tan \alpha)^{n} & =C_{3} x / y^{2} .
\end{aligned}
$$

Case (b) (present work):

$$
C_{4}(y \tan \alpha)^{m}=v_{x \mathrm{~m}} \quad \text { (because of assumption (I)) }
$$

$C_{4}$ is a function of the bottom temperature $T_{B}$ but, according to assumption (3), a constant.

$$
\begin{aligned}
v_{x \mathrm{~m}} & =\left(a_{0} x+\frac{1}{2} z x^{2}\right) / y \quad(\text { according to Equation (2)); } \\
(y \tan \alpha)^{m} & =C_{5}\left(x+z x^{2} / 2 a_{0}\right) / y .
\end{aligned}
$$

Cases (a) and (b) differ by the quadratic term in the numerator and by a factor $y$ in the denominator. The latter can be viewed in the following way: $v_{x}$ and therefore $v_{x \mathrm{~m}}$ are obtained by integration of $\dot{\epsilon}$ from the bedrock to the ice surface. For a given shear stress at the bottom, this integral is independent of $y$ in case (b), since the soft layer near the bottom is a result of the increased temperature in this region. This means, that its thickness does not increase with $y$. In case (a), however, the soft layer is a result of shear stress, so that its increase in thickness is proportional to the height $y$.

It is interesting to see by what amount the exponent $m$ in case (b) differs from $n$. Division of Equation (5) by Equation (3) yields:

$$
(y \tan \alpha)^{m-n}=C_{6} y\left(\mathrm{r}+z x / 2 a_{0}\right)
$$

The second factor on the right-hand side of Equation (6) is a decreasing function of $x$, while the third factor is an increasing function of $x$. For the Greenland surface profile considered, the right-hand side of Equation (6) is almost constant; it has incidentally the same value at both standard points $\mathrm{A}(x=\mathrm{o} \mathrm{km})$ and c $(x=38 \mathrm{o} \mathrm{km})$ of Haefeli and Brandenberger (1968, p. 278). Because of this it is a good approximation to use the average value $m=n$ in Equation (6) for the whole range of $x$ (o to $500 \mathrm{~km}$ ).

We can sum up our result in the following way: The thermal softening of the bottom layer and the accumulation, which increases with $x$, should lead to $m \neq n$. But these two influences are operating in opposite directions; in the region considered here (the E.G.I.G. profile) they approximately cancel each other. This means that in both cases (a) and (b) the best description of the measured profile is obtained if, in Glen's law, the exponent is taken as $n=3 \cdot 5$. This result is very satisfactory, since $n \approx 3.5$ is also obtained in laboratory measurements on the mechanical properties of ice.

If we drop now assumption (3), the bottom temperature $T_{B}$ becomes a function of $x$.

Using the generalized Glen's law modified by Lliboutry (1968), Equation (5) becomes

$$
(y \tan \alpha)^{m} \exp \left[k\left(T_{B}-S\right)\right]=C_{7}\left(x+z x^{2} / 2 a_{0}\right) / y,
$$

where $S$ is the pressure melting point. 
Division of Equation (7) by Equation (3) yields

$$
(y \tan \alpha)^{m-n} \exp \left[k\left(T_{B}-S\right)\right]=C_{8} y\left(\mathrm{r}+Z x / 2 a_{0}\right) .
$$

To simplify the calculation we consider, for the moment, the right-hand side of Equation (8) to be constant (compare the remarks following Equation (6)).

Equation (8) now yields

$$
T_{B}-S=C_{9}-(m-n) \ln (y \tan \alpha) / k .
$$

Equation (9) shows that for a given $y=y(x), \tan \alpha=\tan \alpha(x)$ and $S=S(x)$ there is a definite relationship between the temperature at the bottom and the exponent $m$ ( $n$ is always 3.5). Together with Equation (3) and with $k=0.15 \mathrm{deg}^{-1}$, Equation (9) can be written:

$$
\tau_{B}-S=C_{10}-\frac{m-3 \cdot 5}{0.5^{2}} \ln \left(\frac{x}{y^{2}}\right) .
$$

For $x \rightarrow$ o, i.e. in the vicinity of the ice divide, Equation (10) is no longer valid; but it is evident that in a small region around the ice divide it is very difficult to detect any difference between the measured and the theoretical surface profiles. In the evaluation of Equation (Io) we will consider only values of $x>$ roo km. The constant $C_{\mathrm{ro}}$ cannot be determined from the surface profile. We will therefore refer to an arbitrarily chosen reference point $\mathrm{P}_{0}$, where the values are denoted by a subscript 0 .

$$
\Delta T_{B}=T_{B}-T_{B 0}=S-S_{0}-\frac{m-3 \cdot 5}{0.52} \ln \left(\frac{x y_{0}^{2}}{x_{0} y^{2}}\right)
$$

In Table I some values for $\Delta T_{B}$, calculated for the Greenland surface profile, are given.

From Table I we can draw two important conclusions:

(I) We expect $\Delta T_{B}$ to increase towards the coast, since the heat of friction near the bedrock and the surface temperature both increase; it follows that the exponent $m$ in Glen's law must be smaller than 3.6 .

(2) According to the observations of most workers, $m$ cannot be smaller than 3.0 ; we therefore

\begin{tabular}{|c|c|c|c|c|c|c|c|c|c|}
\hline & $\begin{array}{c}x \\
\mathrm{~km}\end{array}$ & $\begin{array}{l}y \\
\mathrm{~m}\end{array}$ & $\begin{array}{c}S \\
\operatorname{deg}\end{array}$ & \multicolumn{6}{|c|}{$\Delta T_{B}=T_{B}-T_{B 0} \operatorname{deg}$} \\
\hline$P_{0}$ & II 4 & 2984 & -1.9 & o & 0 & o & o & 0 & $0^{\mathrm{T}}$ \\
\hline & 209 & 2730 & -1.8 & 0.9 & 0.6 & 0.2 & o & -0.3 & -0.6 \\
\hline & $\begin{array}{l}247 \\
380\end{array}$ & $\begin{array}{l}2603 \\
2000\end{array}$ & $\begin{array}{l}-1.7 \\
-1.3\end{array}$ & $\begin{array}{l}1.2 \\
2.6\end{array}$ & $\begin{array}{l}0.8 \\
\text { ז.8 }\end{array}$ & $\begin{array}{l}0.3 \\
0.6\end{array}$ & O.I & -0.4 & -0.8 \\
\hline & & & & & & & 0.2 & -0.5 & -1.3 \\
\hline
\end{tabular}
conclude that the bottom temperature between $x=114 \mathrm{~km}$ and $x=38 \mathrm{o} \mathrm{km}$ cannot increase by more than $\approx 2.6 \mathrm{deg}$.

TAble I. Calgulated values of the basal temperature Difference

We see that, towards the coast, the increase of the bottom temperature is only small, but the heat of friction in the lowermost layers (Lliboutry, 1968 ) and the surface temperatures increase rapidly. How are these two statements compatible? One can only conclude that, in the outer regions, part of the heat is used in the melting process. This means that the pressure-melting point at the ice-bedrock interface is reached at a relatively small distance from the ice divide $(c .150 \mathrm{~km})$, and that friction forces are responsible for the shear stress at the bottom (Haefeli, 1968). Finally we would like to mention that by an entirely different reasoning (Philberth and Federer, to be published) a higher bottom temperature can be expected than has been assumed hitherto.

MS. received 26 fuly 1969

\section{REFERENCES}

Benson, C. S. 1962. Stratigraphic studies in the snow and firn of the Greenland ice sheet. U.S. Snow, Ice and Permafrost Research Establishment. Research Report 70.

Federer, B. 1969. Nivologische Arbeiten der Internationalen Glaziologischen Grönlandexpedition EGIG 1968. Eidg. Institut für Schnee- und Lawinenforschung, Weissfluhjoch/Davos. Interner Bericht, Nr. $49 \mathrm{I}$. Haefeli, R. I96r. Contribution to the movement and the form of ice sheets in the Arctic and Antarctic. Fournal
of Glaciology, Vol. 3, No. 30, p. I $133^{-5}$ I. 
Haefeli, R. 1968. Gedanken zum Problem der glazialen Erosion. Rock Mechanics and Engineering Geology: Felsmechanik und Ingenieurgeologie, Suppl. 4, p. 31-5i.

Haefeli, R., and Brandenberger, F. 1968. Rheologisch-glaziologische Untersuchungen im Firngebiet des grönländischen Inlandeises. Meddelelser om Gronland, Bd. I77, Nr. I.

Lliboutry, L. 1968. Steady-state temperatures at the bottom of ice sheets and computation of the bottom ice flow law from the surface profile. Fournal of Glaciology, Vol. 7, No. 51, p. $363_{3}-76$.

Mock, S. J. 1967. Calculated patterns of accumulation on the Greenland ice sheet. Fournal of Glaciology, Vol. 6, No. 48, p. 795-803.

Nye, J. F. 1959. The motion of ice sheets and glaciers. Fournal of Glaciology, Vol. 3, No. 26, p. 493-507.

Quervain, M. R. de. I968. Schneekundliche Arbeiten der Internationalen Glaziologischen Grönlandexpedition (EGIG I). Meddelelser om Grenland, Bd. 177, Nr. 4 .

Robin, G. de Q. 1955. Ice movement and temperature distribution in glaciers and ice sheets. Journal of Glaciology, Vol. 2, No. 18, p. 523-32.

Weertman, J. r96r. Equilibrium profile of ice caps. Journal of Glaciology, Vol. 3, No. 30, p. 953-64.

\section{APPENDIX}

To simplify the calculations we considered the right-hand side of Equation (8) to be constant. In reality it increases from $x=0$ until $x=209 \mathrm{~km}$ by $12 \%$ and then decreases. Between the reference point $(x=114 \mathrm{~km})$ and point $\mathrm{c}(x=380 \mathrm{~km})$ the decrease is $10 \%$. According to Equation (8) this variation corresponds to a change in the bottom temperature $T_{B}$ of $0.6 \mathrm{deg}(\operatorname{since} \exp (0.15 \times 0.6)=\mathrm{I} . \mathrm{I})$. This means that in Table I at $x=38 \mathrm{okm}$ the temperature differences $\Delta T_{B}$ become lower by $0.6 \mathrm{deg}$. This change supports the consequences drawn from Table I favourably. 